\section{PATTERNS OF SILVER HOARDING IN MIDDLE ROMAN PALESTINE: AD 73-300'}

\begin{abstract}
Middle Roman Palestine encompasses the period between the end of the First Jewish Revolt in AD 70-73 and the Christianisation of Palestine in the early fourth century. The greatest concentration of hoards from this phase was during the Second Jewish Revolt (Bar Kokhba Revolt) between AD 132 and 135/136, providing a wealth of information about precious metal hoarding patterns, especially during periods of conflict. The Crisis of the Third Century also influenced hoarding patterns in Palestine, potentially illustrating a causation between enacted monetary reforms and reactionary increases in hoarding. Additional topics that will be explored within this hoard evidence include denominations of silver coins, reigns and mints represented, and quantities of hoards and coins. These facets will illuminate aspects of silver hoarding in second- and third-century Palestine.
\end{abstract}

Keywords: Silver, Hoard, Roman, Palestine, Israel.

\section{INTRODUCTION}

$\mathbf{T}$ he Middle Roman period of Roman Palestine ${ }^{2}$ began after the widespread destruction caused by the First Jewish Revolt (66-70/3), which climaxed with the razing of Jerusalem in $\mathrm{AD} 70$. It is difficult to discern much about the period between the First Jewish Revolt and the Second, led by Simon Bar Kokhba (Ben Kosiba) between $\mathrm{AD} 132$ and $\mathrm{AD}$ 135-136. The hoard record between $\mathrm{AD}$ 70-73 and AD 132 is notably sparse, and many of the

\footnotetext{
${ }^{1}$ This paper summarizes many of the patterns and conclusions observed in my unpublished M.Phil. thesis, Coin Hoards of Roman Palestine: 63 BC-AD 300, University of Oxford (2017). I would like to acknowledge Prof. Chris Howgego and Dr. Donald T. Ariel for their significant contributions to the development of this research, and the generosity of the Israel Antiquities Authority (IAA) with their hoard data, both published and unpublished.

2 'Syria-Palestine' or 'Roman Palestine' corresponds with modern Israel and the disputed Palestinian territories, including Gaza, the West Bank, and the Golan Heights.
}

\section{Joshua Goldman}

Independent Researcher

Goldman.archaeology@gmail.com

DOI: 10.14795/j.v7i1_SI.484

ISSN $2360-266 \mathrm{X}$

ISSN-L 2360 - 266X 


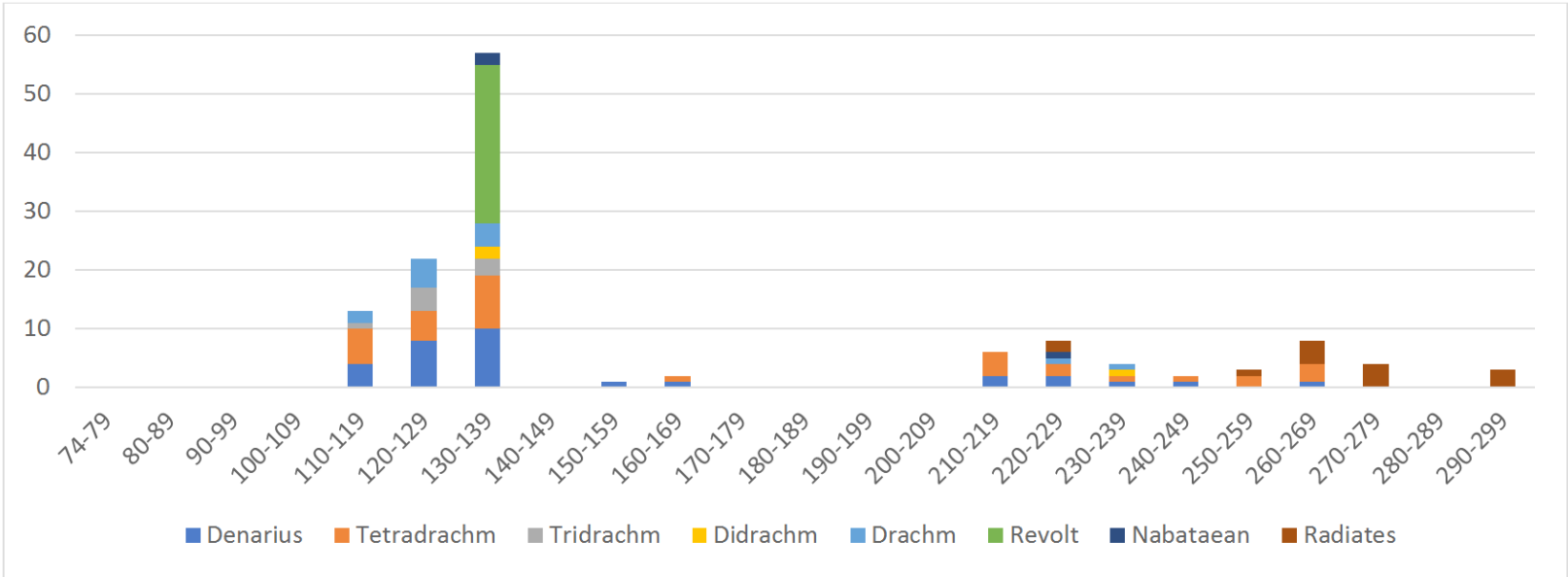

Fig. 1. Number of hoards with each silver denominations present, organised by t.p.q.

depositions are probably more accurately dated to the revolt phase. In contrast, $\mathrm{AD}$ 132-136 represents the densest period of coin hoarding in Roman Palestine, ${ }^{\mathbf{3}}$ producing an especially robust precious metal hoard record, including rare gold and jewellery treasures.

The period between the end of the Bar Kokhba Revolt and the Christianisation of Palestine in the early fourth century has not yet been adequately explored numismatically. ${ }^{4}$ Few hoards are known, and the reasons for deposition were probably the result of monetary reforms, such as the introduction of the silver radiate antoninianus in $\mathrm{AD}$ 215 , rather than violent conflicts. By $A D$ 268, all civic mints in the Levant had ceased provincial coin production and new issues were restricted to imperial mints. ${ }^{5}$ During the reign of Aurelian (AD 270-275), the emperor initiated the production of heavier radiate coins ("aureliani"). The currency reforms of Diocletian in 293/294-296 again transformed the composition of the hoards in Roman Palestine, marking a logical end to the Middle Roman period and the beginning of the Late Roman hoard evidence.

This chapter utilizes the Coin Hoards of the Roman Empire Project (CHRE) online database ${ }^{6}$ as a digital concordance, indicated by a unique identification number, which provides the most current information

3 GOLDMAN forthcoming.

4 SAFRAI 1994.

5 GITLER 2012, 494; HOWGEGO 1985, 98.

6 http://chre.ashmus.ox.ac.uk. available about the hoard. Terminus post quem (t.p.q.) is informed by the latest coin in each assemblage.

\section{DENOMINATION}

The silver coins from the hoard evidence were primarily imperial denarii struck in Rome and provincial tetradrachms struck in Antioch and Tyre. Additional types included silver coins from Nabataea, smaller silver denominations from Arabia, and overstruck silver coins from the Bar Kokhba Revolt. As the third century progressed, radiate coins became the most common 'silver' coins found in hoards.

Denarii were found in at least 33 hoards deposited during the Middle Roman period. Republican and imperial denarii were rarely discovered in the hoards from Early Roman Palestine, and the only known examples are from Qumran (7692; t.p.q. 9/8 BC), Beth Likiah (7953; t.p.q. 10 BC - AD 20), and 'Isfiya (7657; t.p.q. AD 52-53). Although it is uncertain when the denarius became a common silver currency in the region, ${ }^{7}$ it nevertheless formed a sizeable portion of the silver in hoards from the second and third centuries. Excluding the overstruck denarii from the Bar Kokhba Revolt and those without clear identification or provenance, there were 27 Republican and 691 imperial denarii from these assemblages.

\footnotetext{
7 cf. LÖNNQVIST 2011, 317-8; RPC I:587; CRAWFORD 1985; BURNETT/CRAWFORD 1987; BUTCHER 2004, 195; ARIEL/FONTANILLE 2012, 35.
} 
Provincial tetradrachms were the most common silver denomination found within the hoard evidence. Although the number of hoards with tetradrachms is similar to the rate for denarii-at least 34 hoards contained tetradrachms-they far surpassed denarii in total number. Excluding the overstruck tetradrachms from the Bar Kokhba Revolt and those without clear identification or provenance, there were 9,806 provincial tetradrachms identified in the hoards. It should be noted that more than 8,000 of these tetradrachms were discovered in the remarkable Mampsis hoard (7616; t.p.q. AD 218-222), a bronze jar filled with nearly 10,500 silver coins and hidden beneath a staircase. ${ }^{8}$

Most of the provincial drachms, didrachms, and tridrachms, were struck during the reign of Trajan at a mint in Arabia. Along with a few hoards which had smaller Nabataean silver coins, no other 'small change' silver was discovered in the hoards from Middle Roman Palestine. Drachms were found in 16 hoards, didrachms in 3 hoards, and tridrachms in 8 hoards. Nabataean silver coins, often identified as drachms, were struck within the external monetary system of the kingdom. Two hoards with Nabataean silver coins are known: Wadi Murabba'at (7690; t.p.q. AD 117-138) included 227 silver coins, 119 of which were Nabataean (52\%), ${ }^{9}$ and 'Ein Feshkha (7586; t.p.q. AD 117-138) included 179 coins, 71 of which were Nabataean (40\%). ${ }^{10}$

The silver coins overstruck by the rebel administration from the Bar Kokhba Revolt were found in more than 27 hoards, none of which had a t.p.q. later than the revolt. This demonstrates that the coins were quickly demonetised following the revolt's conclusion in $\mathrm{AD}$ 135-136. There was considerable disparity in the coin level detail of the Bar Kokhba Revolt hoard publications, and many of the quantities are unknown, often the result of the coins being dispersed through antiquities markets before being accurately

\footnotetext{
8 ROSENTHAL-HEGINBOTTOM 1980, 39.

9 Aretas IV (19), Malichus II (29), and Rabbel II (71).

10 Obodas II/III (1), Aretas IV (15), Malichus II (7), Rabbel II (16), and uncertain Nabataean (32).
}

recorded.

The rebel administration produced flans to fit extant coins to overstrike silver already in circulation. ${ }^{11}$ In most cases, the silver revolt coins were exclusively hoarded with other coins struck by the rebels. This is not surprising given the ideological, geographic, and monetary realities of the revolt. However, there are a few hoards with reduced discrimination, possibly demonstrating the haste in which the hoards were formed or the complexities of regulating the circulation of silver coins. The Zabar Cave hoard (8474; t.p.q. AD 132-136), for example, contained nine coins found in a cloth purse: four Roman denarii, two Arabian drachms, and three silver revolt coins. Similarly diverse assemblages from the Bar Kokhba Revolt were discovered in Khirbet Rafi'a (8178; t.p.q. 117/38) and Hebron (7844; t.p.q. AD 132-136).

These hoards validate that not all silver circulating amongst rebel populations was controlled by the Bar Kokhba administration. There are many potential reasons for this inconsistency. The revolt coins might have been intended to complement and not replace the Roman coinage in the region. Another possibility is that the rebel administration tried and failed to regulate circulation. It has also been suggested that some of the rebels would have deliberately refused to exchange their Roman silver coins for those of the revolt, because Roman silver would have been acceptable across provincial boundaries. ${ }^{12}$

After the introduction of the antoninianus by Caracalla in 215 , the rate of silver hoarding increased and then began to decline over time, gradually being replaced by the debased radiate coins. Examples of mixed silver-radiate hoards, such as the Gush Halav hoard (5502; t.p.q. AD 244-249), the "Schalit" hoard (8014; t.p.q. AD 251-253), the Rafah hoard (7689; t.p.q. AD 261-268), and the Capharnaum hoard (7579; t.p.q. AD 268-269), illustrate this inversion. Radiate coins were usually hoarded with other base-metal coins.

\footnotetext{
11 ESHEL 1995.

12 BIJOVSKY 2004, 248; ESHEL 1995, 80.
} 


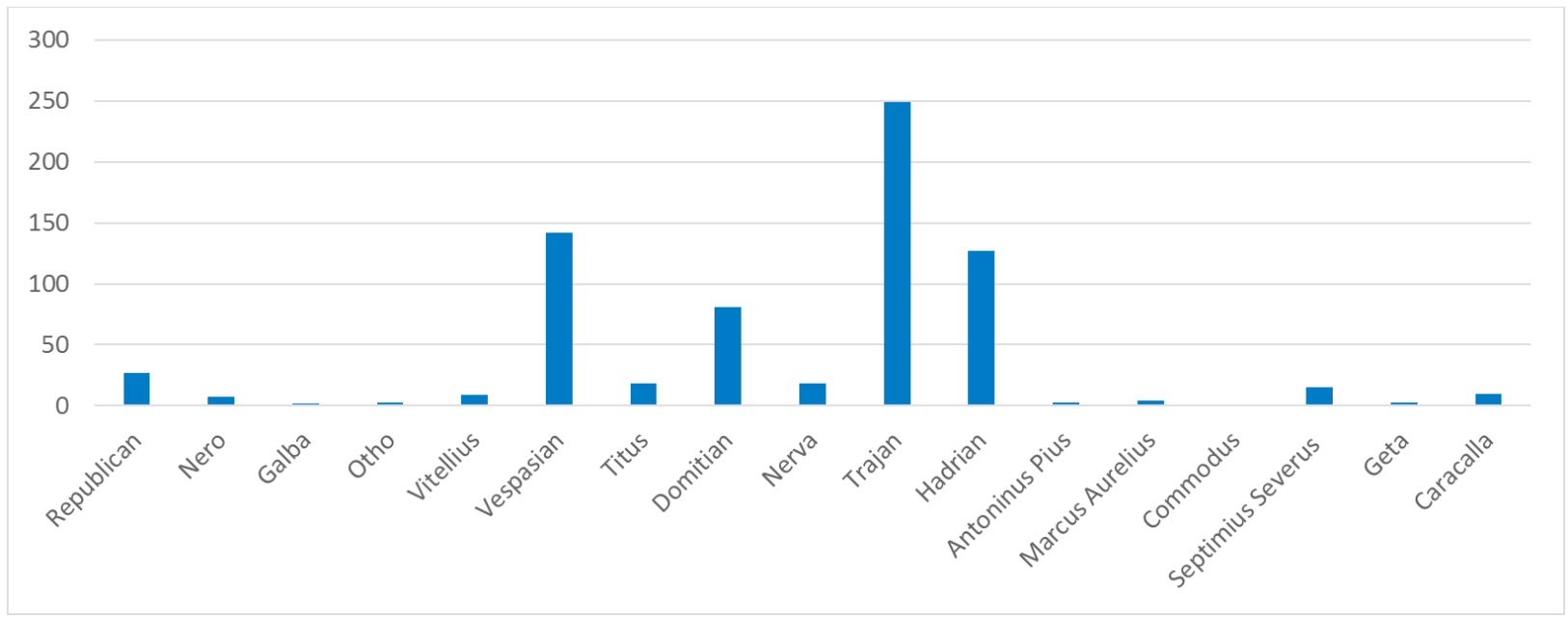

Fig. 2. Number of identified denarii in hoards, organised by reign

\section{REIGN}

The high concentration of hoards from the Bar Kokhba Revolt naturally aligns with higher rates of coins struck during the reigns of Trajan and Hadrian. The apex of denarius hoarding under Trajan probably reflects the rate of circulation from Rome to Palestine, allowing Trajan's denarii sufficient time to permeate the economy more completely than Hadrian's at the outbreak of the revolt in 132. Furthermore, Trajan's eastern campaigns might have caused an increase in denarius circulation from military payments and other expenses.

The number of Hadrianic denarii represented is significantly higher than Hadrianic tetradrachms, and fewer than 40 provincial tetradrachms struck by Hadrian are known from the hoard evidence, compared with nearly 800 of Trajan. This stark difference could be the result of innumerable factors, from natural circulation patterns to targeted actions by the Bar Kokhba rebels. For example, if the narrative in Cassius Dio is accepted as true, the rebels might have had a zealous aversion to the coins of Hadrian after his role in building the temple to Jupiter in Jerusalem. ${ }^{13}$ The recency of Hadrian's coinage might have caused it to be overstruck in greater quantities.

An alternate explanation could be that the sheer quantity of Trajanic silver coins was such that fewer new coins were needed

\footnotetext{
13 Cassius Dio 69:12-15.
}

in the region. ${ }^{14}$ In addition to the prominence of Trajanic denarii and tetradrachms in the assemblages, one must also consider the drachms, didrachms, and tridrachms struck under Trajan in Arabia. These factors might have contributed to the numerical disparity between the two reigns.

Silver coins struck in the late first century under Nero and Vespasian were also common in hoards. Before the reign of Nero, Antiochene tetradrachms circulated in Northern Syria and Tyrian tetradrachms circulated in Phoenicia, Southern Syria, and Palestine. ${ }^{15}$ In AD 59-60, Nero established the value of the Antiochene tetradrachm at four denarii ${ }^{16}$ and in 64 the silver content of the denarius fell from $98 \%$ to $80 \% .{ }^{17}$ This debasement probably undervalued the finer Tyrian silver, rendering it incompatible with other coins in circulation and leading to its withdrawal during the early part of the $2^{\text {nd }}$ century AD. ${ }^{18}$ Neronian tetradrachms from Antioch quickly gained prominence in Middle Roman hoards, increasing from 11 known tetradrachms before the First Jewish Revolt ${ }^{19}$ to nearly AD 200 after.

\footnotetext{
14 BUTCHER 2004, 92; MCALEE 2007, 216.

15 BUTCHER/PONTING 2009, 60.

16 BUTCHER/PONTING 2009, 60.

17 BUTCHER/PONTING 2005, 175-9.

18 BUTCHER/PONTING 2009, 76.

19 Tell el-Far'ah (8086; t.p.q. AD 58-59), Gamla (7592; t.p.q. AD 60-63), Shahariyem (7956; t.p.q. AD 66-70), Dominus Flevit (7605; t.p.q. AD 70-71).
} 


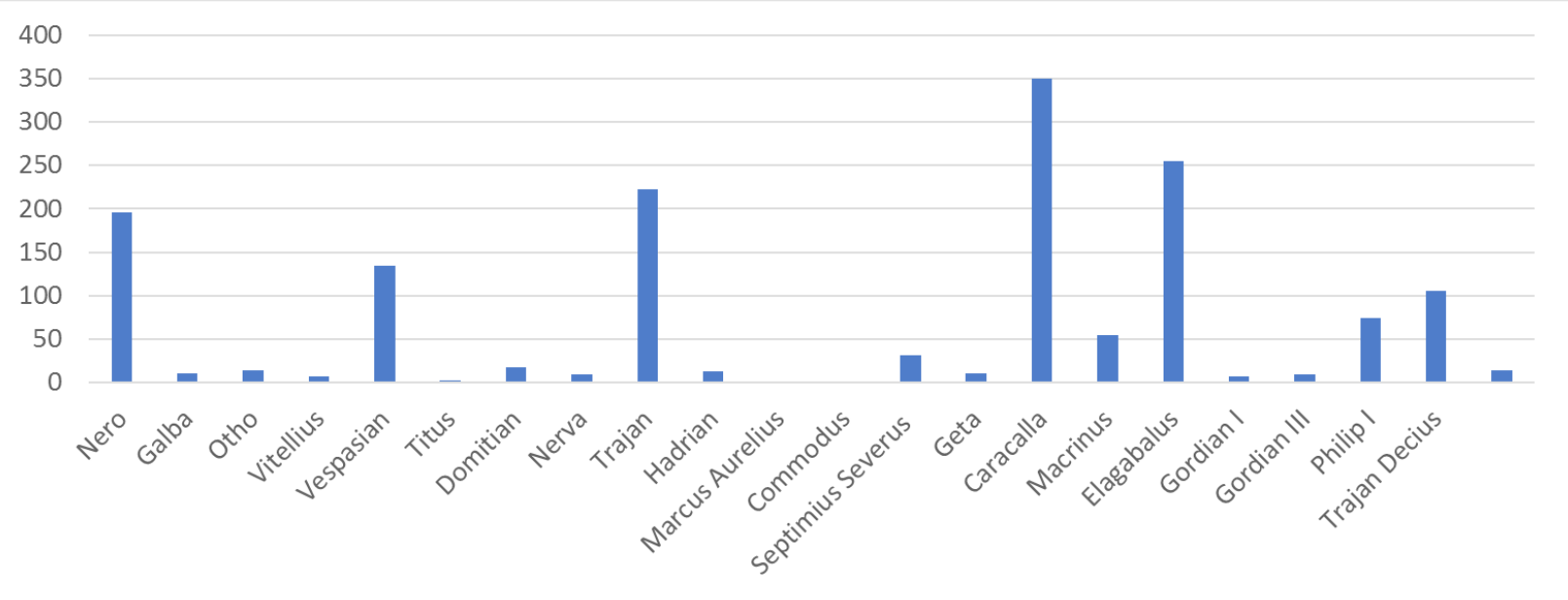

Fig. 3. Number of identified tetradrachms in hoards, organised by reign ${ }^{20}$.

The influx of silver coins - both denarii and tetradrachms - during the reign of Vespasian was probably a direct result of the First Jewish Revolt and the continued military presence in Palestine until the limes expanded to Arabia in AD 106. Vespasian is the first Roman emperor of which substantial quantities of denarii have been discovered across a series of Palestinian hoards: Nero (7 denarii), Galba (2), Otho (3), Vitellius (9), Vespasian (142). ${ }^{21}$ This sizable growth could be evidence of 'Romanisation' through the forced integration of Judaea into the Roman monetary system, or possibly the effects of military payment on circulation during and after the revolt. Vespasianic tetradrachms were discovered in a military assemblage from Masada (7281; t.p.q. AD 107-110) after the garrison was abandoned, ${ }^{22}$ providing rare evidence of local military payment.

Overall, the rate of silver in hoards starkly decreased after the revolt and experienced a slight uptick during the Severan period, probably as a result of the monetary reforms of Caracalla. ${ }^{23}$ The indicative quality of these reactionary hoards is the preservation

\footnotetext{
20 This figure only includes tetrADrachms which can be clearly identified. The Mampsis hoard (7616; t.p.q. AD 218/22) has been excluded due to the volume of coins in the assemblage.

${ }^{21}$ n.b. The singular 'Isfiya hoard (7657; t.p.q. AD 52/3) included at least 160 denarii of Augustus.

22 MESHORER 1989, 77.

${ }^{23}$ Ain Hanaziv (7562; t.p.q. AD 210/1).
}

of earlier silver coins in the assemblages. For example, in a hoard from Ain Hanaziv (7562; t.p.q. AD 210-211), the silver coins were all denarii from the Antonine period (TrajanMarcus Aurelius), with one later denarius of Septimius Severus.

Although the denarius would never return to early second-century hoard levels, there were larger and more diverse tetradrachm assemblages from the Severan period. As shown in figure 3 below, the highest volume of tetradrachms represented within the hoard evidence were those of Caracalla and Elagabalus. Denarii and tetradrachms continued to be hoarded well into the third century, with the latest known examples closing under Gallienus. ${ }^{24}$

\section{MINT}

The overwhelming majority of denarii were struck in Rome, although certain hoard publications recorded denarii struck in Antioch, ${ }^{25}$ Asia, ${ }^{26}$ Bostra, ${ }^{27}$ and Laodicea ad Mare. ${ }^{28}$ The mint for the Trajanic drachms,

\footnotetext{
24 Horbat WerADim (7736; t.p.q. AD 255/68), Rafah (7689; t.p.q. AD 261/8), Capharnaum (7579; t.p.q. AD 268/9)

25 Amazia (7733; t.p.q. AD 125-128), Horbat Zalit (7702; t.p.q. AD 128-129).

26 Amazia (7733; t.p.q. AD 125/8), Horbat WerADim (7736; t.p.q. AD 255-268)

27 Avdat (7740; t.p.q. AD 113); Hebron Area (8669; t.p.q. AD 134-135).

28 Gush Halav (5502; t.p.q. AD 244-249).
} 
Table 1. Tetradrachm mint diversity in Middle Roman hoards

\begin{tabular}{|c|c|c|c|}
\hline Mint & Total without Mampsis & Mampsis Hoard (7616) & Total \\
\hline Aelia Capitolina (Judaea) & 3 & 4 & 7 \\
\hline Antioch (Syria) & 323 & 2,506 & 2,829 \\
\hline Beroea (Macedon) & 6 & 1 & 7 \\
\hline Berytus (Phoenicia) & 13 & 20 & 33 \\
\hline Caesarea (Cappadocia) & 1 & 0 & 1 \\
\hline Caesarea Maritima (Samaria) & 6 & 4 & 10 \\
\hline Carrhae (Mesopotamia) & 8 & 8 & 16 \\
\hline Cyrrhus (Cyrrhestica) & 4 & 1 & 5 \\
\hline Damascus (Syria) & 2 & 5 & 7 \\
\hline Edessa (Mesopotamia) & 5 & 2 & 7 \\
\hline Emesa (Syria) & 12 & 7 & 19 \\
\hline Gabala (Syria) & 1 & 0 & 1 \\
\hline Gadara (Decapolis) & 1 & 0 & 1 \\
\hline Gaza (Judaea) & 3 & 0 & 3 \\
\hline Heliopolis (Syria) & 1 & 2 & 3 \\
\hline Hierapolis (Phrygia) & 6 & 3 & 9 \\
\hline Koinon of Cyprus & 2 & 5 & 7 \\
\hline Laodicea ad Mare (Syria) & 35 & 4,242 & 4,277 \\
\hline Neapolis (Samaria) & 0 & 1 & 1 \\
\hline Orthosia (Phoenicia) & 2 & 4 & 6 \\
\hline Rhesaena (Mesopotamia) & 0 & 1 & 1 \\
\hline Seleuceia ad Tigrim (Seleucia) & 2 & 0 & 2 \\
\hline Seleucia Pieria (Syria) & 5 & 11 & 16 \\
\hline Sidon (Phoenicia) & 2 & 1 & 3 \\
\hline Tripolis (Phoenicia) & 3 & 13 & 16 \\
\hline Tyre & 123 & 823 & 946 \\
\hline Zeugma (Commagene) & 1 & 1 & 2 \\
\hline Total Tetrradrachms & 570 & 7,665 & 8,235 \\
\hline
\end{tabular}

didrachms, and tridrachms was probably located in the Arabian capital, Bostra, ${ }^{29}$ even if many of the hoards still ascribe the coins to Cappadocian Caesarea, as originally proposed by Wroth in 1899. The Bar Kokhba administration did not have access to an established mint, and so they probably utilised mobile ones for overstriking purposes. ${ }^{30}$

29 c.f. WROTH 1899, 54-7, METCALF 1975, 87-108; KINDLER 1983, 95-99; BUTCHER 2010; BUTCHER 2012; RPC III.

30 BARAG 2002; KINDLER 1986-1987.
The principal mint diversity in the Middle Roman hoards occurred within the tetradrachm dataset. The Tyrian tetradrachm, which acted as the primary silver currency in the Early Roman period, became secondary to the Antiochene tetradrachm for the entirety of the Middle Roman period. In total, 2,829 Antiochene and 946 Tyrian tetradrachms were recorded in the hoard evidence. Even with the massive Mampsis hoard excluded, the numbers are 323 and 123 respectively, still demonstrating a substantial difference. 


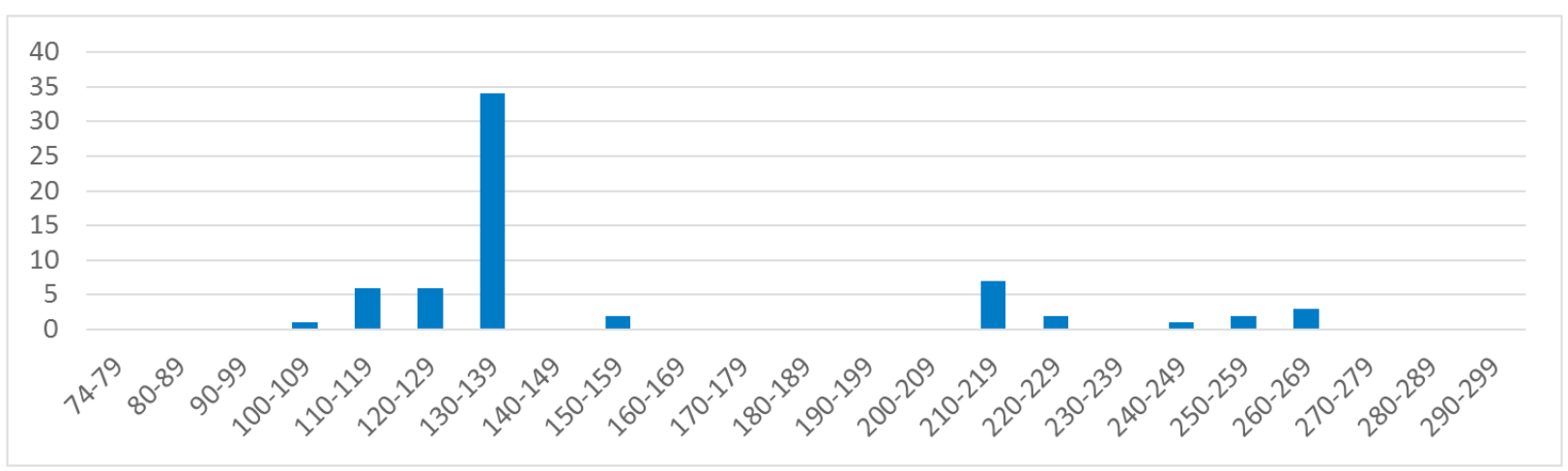

Fig. 4. Number of individual hoards with silver coins, organised by t.p.q.

Whilst every single tetradrachm hoarded in the second century was struck at either Antioch or Tyre, many third-century silver hoards displayed remarkable mint diversity. ${ }^{31}$ During the reign of Caracalla, the production of provincial silver tetradrachms was initiated at twenty-eight new eastern mints. ${ }^{32}$ This significantly increased the number of mints represented in hoards. The following table illustrates the total number of tetradrachms recorded for each mint in the Middle Roman period, with and without the influence of the Mampsis hoard. Notably, the Mampsis hoard increases the percentage of tetradrachms struck in Laodicea ad Mare from 6\% to 55\%.

\section{CONCLUSION}

The Middle Roman period included more silver hoards than any other period in Roman Palestine, probably illustrating a positive correlation between phases of hoarding and violence. ${ }^{33}$ This relationship would account for the extreme increase of silver hoarding during the devastating Bar Kokhba Revolt (132-6). The third-century peaks appear to be reactions to monetary reforms, especially given the prevalence of second-century silver coins in these assemblages.

The absence of silver hoards deposited

\footnotetext{
31 Khirbet Qasta (7904; t.p.q. AD 217-218), Kefar Bara (7706; t.p.q. AD 219-222), Mampsis (7616; t.p.q. AD 218-222), Gush Halav (5502; t.p.q. AD 244-249), Schalit Hoard (8014; t.p.q. AD 251-253) Rafah (7878; t.p.q. AD 251-253), Horbat WerADim (7736; t.p.q. AD 255-268), Rafah (7689; t.p.q. AD 261-268), Capharnaum (7579; t.p.q. AD 268-269).

32 BELLINGER 1940; PRIEUR 2000.

33 CRAWFORD 1969; GOLDMAN forthcoming.
}

during the late second century might reflect a post-revolt calm after the provincial restructuring of Palestine and Arabia. Peaceful conditions would provide for a high rate of hoard recovery, and this hoarding behaviour would also explain the significant increase in ruler diversity in the third-century hoards, which would be characteristic of accumulated savings. The general paucity of pre-Severan silver in the hoard evidence was also probably influenced by the debasement of the denarius in $\mathrm{AD} 194 .^{34}$

The hoards from the second and third centuries are compositional opposites. Despite the severe contrast in total number of hoards, the total number of coins presents a very different narrative. Even with the discrepancies in hoard publication quality, in which many quantities from the Bar Kokhba Revolt are unknown, it is clear that the majority of these hoards were smaller assemblages that could be transported easily on the person of the rebel. Contrarily, many third-century silver hoards contained large and diverse assemblages, which explains why the tetradrachms of Caracalla and Elagabalus are more prominent overall than those of Trajan, even with the Mampsis hoard omitted.

Nevertheless, the data from the Bar Kokhba Revolt is an exemplary case study to explore patterns of silver hoarding. In addition to having a fixed time period, the revolt is bookended by the well-defined hoard profile of the First Jewish Revolt and the nadir in hoarding in the subsequent decades. The

34 DUNCAN-JONES 2001; GITLER/PONTING 2007. 
clarity and definition of this dataset provides unparalleled information about rates of silver hoarding in Roman Palestine, and especially patterns of silver hoarding during periods of crisis.

\section{REFERENCES}

\section{ARIEL/FONTANILLE 2012}

Ariel, D. T./Fontanille, J.-P., The Coins of Herod: A Modern Analysis and Die Classification (Leiden: Brill).

BARAG 2002

Barag, D., The Two Mints of the Bar Kokhba War, Israel Numismatic Journal 14, 153-156.

BELLINGER 1940

Bellinger, A. R., The Syrian tetradrachms of Caracalla and Macrinus (New York: NY Durst).

BIJOVSKY 2004

Bijovsky, G., The Coins from Khirbet Badd 'Isa-Qiryat Sefer. In: Magen, Y./Ariel, D.T./ Bijovsky, G./Zionit, Y./Sirkis, O. (eds), The Land of Benjamin [Judea and Samaria Publications 4] (Jerusalem), 243-300.

BURNETT/CRAWFORD 1987

Burnett, A./Crawford, M. (eds.), The Coinage of the Roman World in the Late Republic: Proceedings of a Colloquium held at the British Museum in September 1985 [BAR International Series 326] (Oxford: BAR).

\section{BUTCHER 2004}

Butcher, K., Coinage in Roman Syria. Northern Syria, 64 BC - AD 253 [Royal Numismatic Society Special Publication 34] (London: Royal Numismatic Society).

BURCHER 2010

Butcher, K., The Complete Bostra, Journal of Roman Archaeology 23, 780-781.

BUTCHER 2012

Butcher, K., The Silver Coinage of Roman Arabia. In: Jacobson, D.M./Kokkinos, N. (eds), Judaea and Rome in Coins 65 BCE 135 CE (London: Spink), 203-13.

BUTCHER/PONTING 2005

Butcher, K./Ponting, M., The Roman denariusunder the Julio-Claudian emperors: mints, metallurgy and technology, Oxford Journal of Archaeology 24/2, 163-97.

BUTCHER/PONTING 2009

Butcher, K., and Ponting, M., The Silver
Coinage of Roman Syria under the Julio-

Claudian Emperors, Levant 41, 59-78.

\section{CRAWFORD 1985}

Crawford, M., Coinage and Money under the Roman Republic: Italy and the Mediterranean economy (London: Methuen).

\section{DUNCAN-JONES}

Duncan-Jones, R., The Denarii of Septimius Severus and the Mobility of Roman Coin, Numismatic Chronicle 161, 75-89.

\section{ESHEL 1995}

Eshel, H., The Policy of Overstriking Roman Coins During the Bar-Kokhba Revolt in Light of Finds in the Judean Desert. In: Y. Eshel (ed.), Judea and Samaria Research Studies. Proceedings of the $5^{\text {th }}$ Annual Meeting. Kedumim- Ariel, 175-82.

\section{GITLER 2012}

Gitler, H., Roman Coinages of Palestine. In: Metcalf, W.E. (ed.), The Oxford Handbook of Greek and Roman Coinage (Oxford: University Press), 485-98.

\section{GITLER/PONTING 2007}

Gitler, H./Ponting, M., Rome and the East. A Study of the Chemical Composition of Roman Silver Coinage during the Reign of Septimius Severus, AD 193-211. In: Sartre, M. (ed.), Productions et échanges dans la Syrie grecque et romaine. Actes du colloque de Tours, juin 2003 [Topoi suppl. 8] (Lyon: Maison de l'orient méditerranéen), 375-97. GOLDMAN 2017

Goldman, J., Coin Hoards of Roman Palestine: 63 BC - AD 300. Unpublished MPhil Thesis, University of Oxford.

GOLDMAN forthcoming

Goldman, J., Coin Hoarding in Roman Palestine: 63 BC- AD 300. In: Coin Hoards and Hoarding in the Roman World (Oxford: University Press).

\section{HOWGEGO 1985}

Howgego, Ch., Greekimperial countermarks.

Studies in the provincial coinage of the

Roman Empire [Royal Numismatic Society

17] (London: Royal Numismatic Society).

\section{KINDLER 1983}

Kindler, A., The Coinage of Bostra (Warminster: Aris \& Phillips).

\section{KINDLER 1986-1987}

Kindler, A., Coins and Remains from a Mobile Mint of Bar Kokhba at Khirbet el'Aqd. Israel Numismatic Journal 9, 46-50. 


\section{LÖNNQVIST 2011}

Lönnqvist, K., The Date of Introduction of Denarii to Roman Judaea and the Decapolis Region, Aram 23, 307-18.

MCALEE 2007

McAlee, R., The Coins of Roman Antioch (Lancaster, PA: Lancaster Classical Numismatic Group).

MESHORER 1989

Meshorer, Y., The Coins of Masada. In: Aviram, J./Foerster, G./Netzer, E. (eds.), Masada: the Yigael Yadin excavations, 19631965, I /The Aramaic and Hebrew ostraca and jar inscriptions [Masada 1] (Jerusalem: Israel exploration Society), 71-132.

METCALF 1975

Metcalf, W.E., The Tell Kalak Hoard and Trajan's Arabian Mint, American Numismatic Society Museum Notes 20, 39-108.

\section{PRIEUR/PRIEUR 2000}

Prieur, M./Prieur, K., A Type Corpus of the Syro-Phoenician Tetradrachms and their Fractions from 57 BC to AD 253 (London: Chamaleon Press).

ROSENTHAL-HEGINBOTTOM 1980

Rosenthal-Heginbottom, R., The Mampsis Hoard - A Preliminary Report, Israel Numismatic Journal 4, 39-54.

SAFRAI 1994

Safrai, Z., The Economy of Roman Palestine (London: Routledge).

WROTH 1899

Wroth, W., A Catalogue of the Greek Coins in the British Museum: Galatia, Cappadocia and Syria (London). 
